Egyptian Journal of Rabbit Science, 26(2): 175-194 (2016)

\title{
REPLACEMENT OF ALFALFA HAY BY MORINGA PETIOLES MEAL WITH OR WITHOUT ADDING CAPLIX IN GROWING RABBIT DIETS.
}

\author{
H.M. Sobhy ; A.A.M. Soliman ${ }^{2}$; M.R.M. Ibrahim ${ }^{3}$;; Thanaa.F. Mohammadi ; \\ M.S.Abouskken ${ }^{5}$; and A.A.M.Ahmed ${ }^{4}$ \\ 1. Department of natural resources, Research Institute of African Studies. \\ Cairo University, Giza, Egypt. \\ 2. Animal Nutrition Department, Animal Production Research Institute, \\ Agricultural Research Center, Dokki, Giza, Egypt. \\ 3. Animal Production Department, Faculty of Agriculture, Cairo University, Egypt. \\ 4. Regional Center for Food and Feed, Agricultural Research Center, Giza, Egypt. \\ 5. Environmental studies and Research Institute, Sustainble Department \\ University of Sadat City, Monofeya, Egypt.
}

A total number of 72 New Zealand White (NZW) growing rabbits of mixed sex, 6 weeks old with $500 \pm 13.75$ g average body weight was used to study the effect of using different levels of Moringa petioles meal without or with supplementation of multi enzymes caplix on rabbit performance, nutrients digestibility, caecum activity, carcass characteristics and economic efficiency. Rabbits were divided into 6 treatments 12 rabbits each. Three substitution levels of Moringa petioles meal were used (zero, 25 and 50\%) instead of Alfalfa dehydrate meal of control diet, with or without caplix addition at levels of 0.00 or $0.05 \%$ of diet in $3 \times 2$ factorial design.

Results indicated that, chemical analysis contents of Moringa petioles meal was higher in DM, OM, CP, EE, Ash, Cell., $P$ and DE than Alfalfa dehydrate meal. While Alfalfa dehydrate meal was higher in $C F, N F E, N D F, A D F, A D L$, Hemi., Lig. and Ca. most nutrients digestibility were improved $(P<0.05)$ with replacing Alfalfa dehydrate meal by Moringa petioles meal at level 25 or 50\%. Also, adding caplix to rabbit diets improved the nutrients digestibility and nutritive values compared to the unsuplemented diets. Caecum weight and TVF'S caecal juice concentrations increased $(p<0.05)$ with replacing Moringa petioles meal compared to the control group. Adding caplix to rabbit diets increased $(P<0.05)$ caecum weight, caecum length, 
caecum $p H$ and TVFA'S concentrations compared to the unsuplemented diets. Using Moringa petioles meal in rabbit significantly $(P<0.05)$ increased the average values of $F B W, D B W G$ and DFI and also with adding caplix in rabbit diets compared to those groups fed diets without caplix. Carcass weight and total edible parts $\%$ increased $(P<0.05)$ with either adding caplix or Moringa petioles meal at levels 25 and 50\% compared to the control group. The tested diets not affect significantly meat content of DM, CP and EE. Replacement Alfalfa hay by Moringa petioles meal level or adding caplix did Replacing Moringa petioles meal for at level of 25 or $50 \%$ either with or without adding caplix to rabbit diets improved the economic efficiency.

Conclusively, replacement of 50\% of alfalfa hay in the rabbits diet by moringa petioles meal with $0.05 \%$ caplex supplementation could be recommanded to improve rabbit growth performance parameters and feed efficiency of feed utilizationunder the Egyptian conditions.

Keywords: Moringa petioles meal, caplix, growth performance, digestion, carcass characteristics.

In developing countries such as Egypt and South Africa the shortage of feedstuffs and its high cost are major represents a main problems facing the development of animal productivity. Many efforts have been made to solve the feeds shortage by improving the productivity of conventional feed sources and search about new unconventional feeds for animal feeding.

Moringa oleifera $L$ commonly known as "The Miracle Tree or Horseradish Tree", it is a good source of nutrients for human and animal feeding. Moringa leaves have been reported to be a valuable source of protein, vitamins (A, B-complex, C, D and K) beside some important macroelements as calcium, potassium. Zinc, iron, copper and selenium (Dorga, and Tandon, 1975 and Booth and Wickens, 1988). Moreover, it was reported that Moringa oleifera leaves prevent effectively morphological changes and oxidative damage in human and animals by enhancing the activities of antioxidant enzymes, reducing the intensity of lipid peroxidation and inhibiting generation of free radicals (Sreelather and Padma, 2009. and Osman et al., 2012). 
REPLACEMENTOFALFALFAHAYBYMORINGAPETIOLES INRABBITDIETS 177

In Egypt, great attention has been given by plant breeders to implant Moringa oleifera imported seeds in agricultural and newly reclaimed lands for human and animal uses. Moringa plants are grown for many agricultural and industrial purposes. It can be grown well in a variety of soil conditions preferring well-drained sandy or loamy that is slightly alkaline (Kristin, D., 2000 and Luqman et al., 2012). Little have been conducted on the effects on the effects of feeding moringa plants for tea moringa tea or as a fodder for animal feeding.

Adding enzymes to the diets of non ruminant animals particularly poultry, become more common in the recent years to improve digestibility of starch and non-starch polysaccharides of dietary cereals (Campbell and Bedford, 1992). These enzymes can partially hydrolyze non soluble protein, reduce viscosity of gut contents and improvements in nutrients absorption, fiber digestibility (Bolis et al., 1996 and Fernandez et al., 1996).

Therefore, the main objective of the present investigation is to evaluate the effect of dietary substitution of 25 and $50 \%$ of alfalfa hay by Moringa petioles meal wit or without multi enzymes preparation on growth performance, nutrients digestibility and carcass characteristics of growing rabbits.

\section{MATERIALS AND METHODS}

The present experiment was carried out at the farm of Environmental Studies Institute, Sadat City University, Monofeya, Egypt during November and December, 2014. The chemical analysis was conducted at the laboratories of Regional Center For Food and Feed and Animal Production Research Institute. The Moringa oleifera by-products were obtained from the privet farm belonging to El-Minia governorate. The petioles were separate manually and the crushing and milling operations were carried out using a local hammer mill machine at Agricultural Engineering Research Institute, (AENRI). The fine products of petioles were separately pooled each other and on open door-dried to constant moisture levels, and there after bagged for experimental procedures.

A total number of 72 New Zealand White (NZW) mixed sex growing rabbits, six weeks with $500 \pm 2.5 \mathrm{~g}$ average body weight were used for 8 weeks to study the effect of substitution of 25 and $50 \%$ of alfalfa hay by moringa petioles meal levels with or without caplix multi-enzymes supplementation on rabbit performance, nutrients digestibility coefficient, 
carcass characteristic and economic efficiency. Rabbits were randomly divided into 6 equal groups with four replicates ( 3 rabbits each). The rabbits were fed on diets containing 7.5 and $15 \%$ moringa petioles meal to subistitute 25 and $50 \%$ of alfalfa hay in the control diet (Table 1). In each group, diet was fed to the rabbits either un-supplemented or supplemented with caplix $(0.05 \%$ of the diet). The diets were formulated to cover the requirement of growing rabbits according to NRC (1977). Chemical composition of moringa petioles meal and alfalfa dehydrated meal is shown in Table 2. Diets were offered to the rabbits ad-libtum and fresh water was available all the time during the experimental period. Individual live body weight, feed intake and feed conversion ratio were recorded weekly. Three samples of each feed were analyzed to determine the nutrients percentage composition.

Digestibility trials were carried out using four rabbits mix sex from each experimental group at the last week of the experiment. All cages were housed inside a building with a fan to improve the air quality. Rabbits had free access to feed as well as to water. Rabbits were housed in stainless steel cages measuring $100 \times 70 \times 30 \mathrm{~cm}(\mathrm{LWH})$, each containing seven to eight individuals and equipped with a nipple water; the temperature was $13-15{ }^{\circ} \mathrm{C}$ and relative humidity was $60-65 \%$.

Rabbits for each group were housed in metabolism cages where feces and urine were collected separately four 4 consecutive days as a main period. Proximate chemical analysis of the diets and feces were carried out according to the methods of A.O.A.C.( 2002).

At the end of experimental period, four mix sex rabbits were randomly taken from each group and fasted for 12 hours before slaughter according to Blasco et al., (1993). Fasted rabbits were housed in separate cages and kept under the same managerial and hygienic condition. Rabbit meat samples included whole edible meat, including inter muscular fat and tendons. Liver, kidneys and lungs were separated and analyzed as 'rabbit offal'. Rabbit meat samples (a part of the hind leg), each sample was hand-boned and dissected from the fat surface, and the lean part was then finely minced. Samples were prepared for chemical analysis in duplicate for moisture, protein, fat and ash content.

The cecum was immediately exteriorized and caecal contents were removed. The contents from rabbits fed the same ration were pooled and taken to the laboratory for processing within 10 min of collection. A fresh sample strained through four layers of cheesecloth, the filtrate was immediately subjected to 
REPLACEMENTOFALFALFAHAYBYMORINGAPETIOLES INRABBITDIETS 179

Table1. Formulation and Chemical analysis of the experimental diets

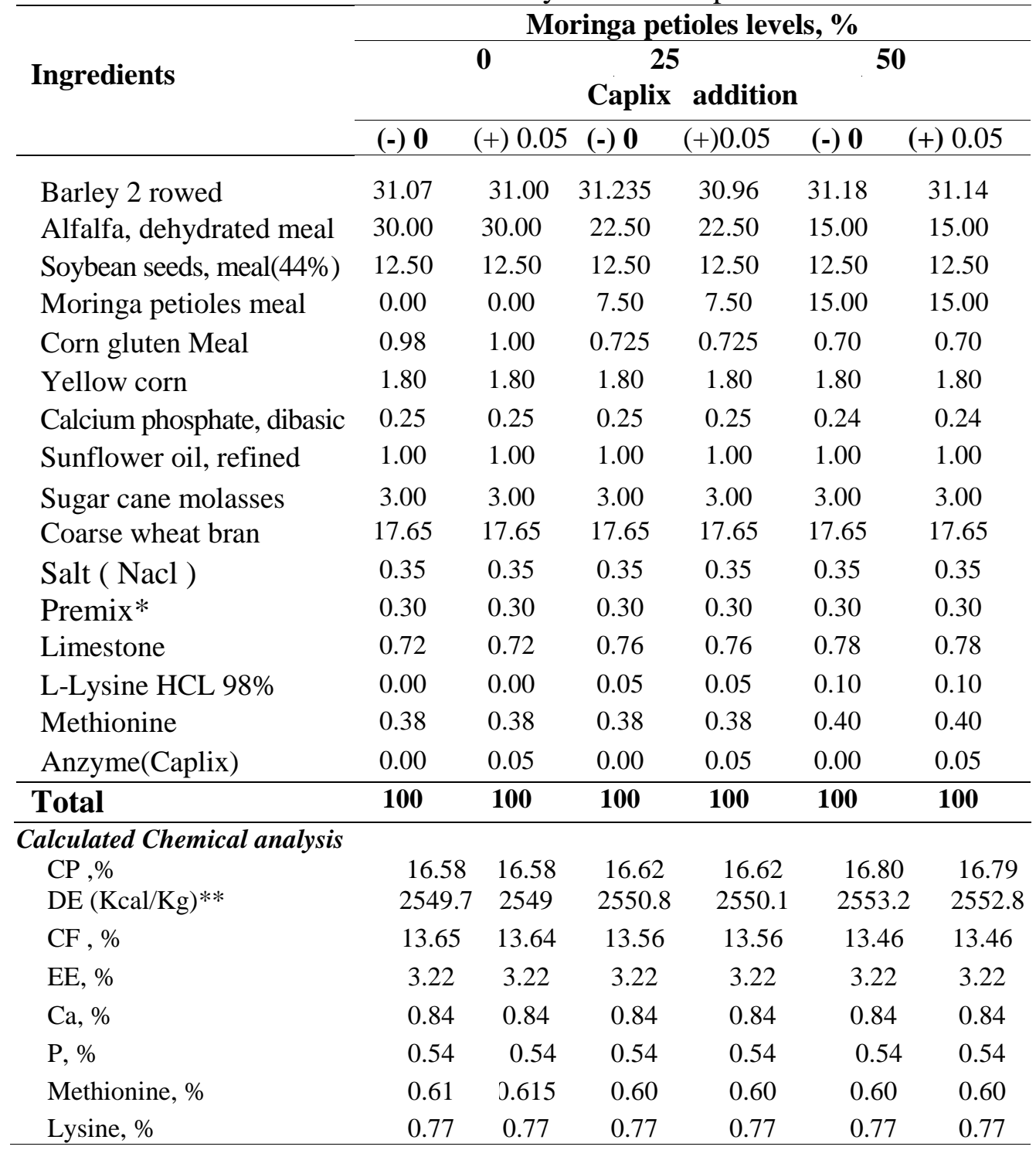

(-) Without Caplix enzyme (+) with Caplix enzyme

*Vitamin and minerals premix at level of $0.3 \%$ of diet supplies the following per $\mathrm{Kg}$ of diet = Vit. A $12000 \mathrm{IU}$, Vit. D3 $2000 \mathrm{IU}$, Vit E $10 \mathrm{mg}$, Vit. K3 2mg, Vit $\mathrm{B}_{1} 1 \mathrm{mg}$, Vit $\mathrm{B}_{2}$ $5 \mathrm{mg}$, Vit. $\mathrm{B}_{6} 1.5 \mathrm{mg}$, Vit. $\mathrm{B}_{12} 10 \mathrm{mg}$; Niacin $30 \mathrm{mg}$, Pantotheanic acid $10 \mathrm{mg}$; Folic acid $1 \mathrm{mg}$, Choine $250 \mathrm{mg}$, Biotin $50 \mathrm{mg}$, Copper 5mg, Manganese $60 \mathrm{mg}$, Zinc 50mg, Iron 30mg, Iodine $0.3 \mathrm{mg}$ Selenium $0.1 \mathrm{mg}$ and Cobalt $0.1 \mathrm{mg}$.

**Calculated according to Fernandez et al., (2004). 
$\mathrm{pH}$ determination with a combination electrode. A portion of the filtrate was sampled and frozen at $-20^{\circ} \mathrm{C}$ for determination of ammonia- $\mathrm{N}$ and volatile fatty acid (TVFA"s) content. Samples for ammonia-N determination were acidified with a solution of $0.2 \mathrm{M}$ hydrochloric acid $(1 \mathrm{ml} / \mathrm{ml})$.

An input - output analysis and economic efficiency were calculated. Economic efficiency of each diets was defined as LE returned for one LE invested in feed. Economic efficiency was calculated by this equation:

Economic efficiency $=($ Selling price of one $\mathrm{kg}$ live body weight Feeding cost of one live body weight / Feeding cost of one $\mathrm{kg}$ live body weight) $\times 100$

All data were subjected to analysis of variance using the generally linear models GLM Procedure of (SAS, 2002) and differences obtained upon statistical analysis were compared using Duncan Multiple Range Test (Duncan, 1955).

\section{RESULTS AND DISCUSSION}

\section{Proximate analysis of alfalfa dehydrated meal and Moringa petioles meal}

The chemical analysis of tested Moringa petioles meal on DM basis compared to alfalfa dehydrated meal is shown in Table 2. The obtained data showed that the moringa petioles meal showed higher contents of DM, OM, $\mathrm{CP}, \mathrm{EE}, \mathrm{Ash}, \mathrm{Cell} ., \mathrm{P}$ and DE than alfalfa dehydrated meal. While alfalfa dehydrated meal was higher in CF, NFE, NDF, ADF, ADL, Hem., Lig. And Ca. In this connection Safwat et al.(2014) reported that Moringa olifera (stems and leaves) contain $23.94 \%$ DM, 21.04\% CP, $15.28 \% \mathrm{CF}, 31.32 \%$ NDF, 26.88\% ADF, 6.25\% EE and 8.89\% ash.

\section{Effect of substitution of alfalfa hay by moringa petioles meal with or without caplix on:}

\section{a. Digestibility and nutritive value}

Digestion coefficients of DM, OM, CP, EE, CF, NFE, NDF, ADF, ADL, Hemicellulose, Cellulose and Lignin, were significantly $(\mathrm{P}<0.05)$ increased as affected by substitution of 25 and $50 \%$ alfalfa hay by moringa petioles meal compared to the control group (Table 3). Also, there were significantly $(\mathrm{P}<0.05)$ increases in digestibility of $\mathrm{CP}, \mathrm{EE}, \mathrm{CF}, \mathrm{NDF}, \mathrm{ADF}$, ADL, Hemicellulose, Cellulose and Lignin and nutritive value as TDN and 
REPLACEMENTOFALFALFAHAYBY MORINGAPETIOLES INRABBITDIETS 181 


\section{REPLACEMENTOFALFALFAHAYBY MORINGAPETIOLES INRABBITDIETS 183}

DCP with replacing $50 \%$ alfalfa dehydrated meal by Moringa petioles meal in rabbit diets compared to the control group. In this respect, Dougnon et al (2012), Talha (2013) and El-Badawi et al.(2014) who found that feeding rabbits on diets supplemented with Moringa dried leaves up to $0.3 \%$ was associated with significant $(\mathrm{P}<0.05)$ increases of nutrients digestibility and dietary nitrogen utilization.

The results revealed that adding caplix to rabbit diets containing petioles meal improved the nutrients digestibility and nutritive value compared to the unsupplemented diet. These observations are supported by those reported by Abd El-Latif, et al.(2008) who noticed that rabbits fed 10\% crud fiber provided with enzymes preparation recorded better $(\mathrm{P}<0.05)$ values of dry mater, crude protein and crude fiber digestibility. The authors noted that adding caplix enzymes enhanced microflora growth in the gut and caecum as well as increase the volatile fatty acids production and organic matter digestibility.

The obtained results showed that rabbits fed diet containing 50\% petioles meal with caplix had the best $(\mathrm{P}<0.05)$ nutrients digestibility and nutritive value compared to the other experimental groups.

\section{b. Caecum activity}

Data in Table 4 showed that, caecum weight, caecum length, caecum $\mathrm{pH}$ and total volatile fatty acids (TVFA'S) in caecal juice were higher $(\mathrm{P}<0.05)$ in rabbits fed diets containing $50 \%$ moring petioles meal (MPM) compared to other diets. الجملة ناقصة

volatile fatty acids (TVFA'S) compared to the control group. The recorded value were 10.78 vs. $9.86 \mathrm{~g} ; 12.10$ vs. $11.30 \mathrm{~cm} ; 6.60$ vs. 6.84 and 4.5 vs. $3.85 \mathrm{mq} / 100 \mathrm{ml}$, respectively. Also, the values of weight caecum and TVFA'S caecal juice were significantly higher $(\mathrm{P}<0.05)$ with $25 \%$ replacing level compared to the control group, being 10.43 vs. $9.86 \mathrm{~g}$ and 4.32 vs. 3.85 $\mathrm{mq} / 100 \mathrm{ml}$, respectively.

Adding caplix enzyme to rabbit diets increased $(\mathrm{P}<0.05)$ caecum weight, caecum length, caecum $\mathrm{pH}$ and TVFA'S caecal juice compared to the unsupplemented diets, being 11.12 vs. $9.59 \mathrm{~g} ; 12.33$ vs. $11.15 \mathrm{~cm} ; 6.51$ vs. 6.92 and 4.66 vs. $3.78 \mathrm{mq} / 100 \mathrm{ml}$, respectively.

Data concerning the interaction effect of moringa petioles meal and caplix, showed that the highest values $(\mathrm{P}<0.05)$ for caecum weight, caecum length, caecum $\mathrm{pH}$ and TVFA'S caecal juice were recorded with rabbits group fed 50\% subistitution MPM diet with caplix. The respective values 
Table 4. Caecum activity of growing White New Zeland White rabbits fed the experimental diets. (Means $\pm \mathrm{SE}$ ).

\begin{tabular}{|c|c|c|c|c|}
\hline Items & $\begin{array}{l}\text { Caecum weight } \\
\text { (g) }\end{array}$ & $\begin{array}{c}\text { Caecum length, } \\
\text { (cm) }\end{array}$ & $\begin{array}{c}\text { Caecum } \\
\text { pH }\end{array}$ & $\begin{array}{c}\text { TVFA'S } \\
\text { caecal juice } \\
(\mathrm{mq} / 100 \mathrm{ml})\end{array}$ \\
\hline \multicolumn{5}{|c|}{ Effect of Moringa Petioles meal levels } \\
\hline $\mathbf{0}$ & $9.86^{\mathrm{b}}$ & $11.30^{\mathrm{b}}$ & $6.84^{\mathrm{a}}$ & \multirow{4}{*}{$\begin{array}{c}3.85^{\mathrm{b}} \\
4.32^{\mathrm{a}} \\
4.50^{\mathrm{a}} \\
\pm 0.0625\end{array}$} \\
\hline 25 & $10.43^{\mathrm{a}}$ & $11.83^{\mathrm{ab}}$ & $6.71^{\text {ab }}$ & \\
\hline 50 & $10.78^{\mathrm{a}}$ & $12.10^{\mathrm{a}}$ & $6.60^{\mathrm{b}}$ & \\
\hline $\mathbf{S E}$ & \pm 0.1592 & \pm 0.2212 & \pm 0.0537 & \\
\hline \multicolumn{5}{|c|}{ Effect of Caplix levels (\%) } \\
\hline 0.00 & $9.59^{\mathrm{b}}$ & $11.15^{\mathrm{b}}$ & $6.92^{\mathrm{a}}$ & $3.78^{\mathrm{b}}$ \\
\hline $\begin{array}{l}0.05 \\
\text { SE }\end{array}$ & $\begin{array}{c}11.12^{\mathrm{a}} \\
\pm 0.1300\end{array}$ & $\begin{array}{c}12.33^{\mathrm{a}} \\
\pm 0.1806\end{array}$ & $\begin{array}{l}6.51^{\mathrm{b}} \\
\pm 0.0439\end{array}$ & $\begin{array}{c}4.66^{\mathrm{a}} \\
\pm 0.0510\end{array}$ \\
\hline \multicolumn{5}{|c|}{ Effect of Interaction Moringa Petioles meal X Caplix) } \\
\hline $\mathbf{0}(-)$ & $9.28^{\mathrm{c}}$ & $10.70^{\mathrm{d}}$ & $7.02^{\mathrm{a}}$ & \multirow{7}{*}{$\begin{array}{c}3.36^{\mathrm{d}} \\
4.34^{\mathrm{b}} \\
3.84^{\mathrm{c}} \\
4.79^{\mathrm{a}} \\
4.14^{\mathrm{b}} \\
4.85^{\mathrm{a}} \\
\pm 0.0883\end{array}$} \\
\hline $\mathbf{0}(+)$ & $10.44^{\mathrm{b}}$ & $11.90^{\mathrm{abc}}$ & $6.65^{\mathrm{bc}}$ & \\
\hline $25(-)$ & $9.56^{\mathrm{c}}$ & $11.25^{\mathrm{cd}}$ & $6.95^{\mathrm{a}}$ & \\
\hline $25(+)$ & $11.30^{\mathrm{a}}$ & $12.40^{\mathrm{ab}}$ & $6.46^{\mathrm{cd}}$ & \\
\hline $50(-)$ & $9.94^{b c}$ & $11.50^{\mathrm{bcd}}$ & $6.79^{\mathrm{ab}}$ & \\
\hline $50(+)$ & $11.61^{\mathrm{a}}$ & $12.70^{\mathrm{a}}$ & $6.41^{\mathrm{d}}$ & \\
\hline SE & \pm 0.2251 & \pm 0.3128 & \pm 0.0760 & \\
\hline
\end{tabular}

.a, b, c ......Means within the same column with different letters are significantly different $(\mathrm{P}<0.05)$. (-) Without Caplix $\quad(+)$ With Caplix

were $11.61 \mathrm{~g} ; 12.70 \mathrm{~cm} ; 6.41$ and $4.85 \mathrm{mq} / 100 \mathrm{ml}$. While the lowest values were recorded with that group fed the control diet without caplix. The respective values were $9.28 \mathrm{~g}, 10.27 \mathrm{~cm}, 7.02$ and $3.36 \mathrm{mq} / 100 \mathrm{ml}$.

These results are in agree with those reported by Abd El-Latif, et al. (2008) who noted that caplix enzymes enhance the micro flora growth in the gut and Caecum, as well as increase caecal TVFA's production and organic matter digestibility. Moreover, Abd El-Rahman et al. (2010) indicated that, dietary addition of multi-enzymes for rabbits could lead to favorable modification in gastro-intestine tract (GIT), environment presumably, acidification of caecal contents and stabilization of ammonia nitrogen concentration. These alterations may be improve the caecal fermentation 
REPLACEMENTOFALFALFAHAYBYMORINGAPETIOLES INRABBITDIETS 185

pattern and rabbit metabolism that might lead to higher body weight and increase in efficiency of feed utilization.

\section{c. Growth performance}

Data in Table 5 show that replacing alfalfa hay by moring petioles meal in rabbit diets at level 50\% increase $(\mathrm{P}<0.05)$ the averages final body weight (FBW) and daily weight gain (DWG) and improved feed conversion ratio (FCR) in comparison with the control group. The values were 2112.22 vs. $2017.94 \mathrm{~g} ; 28.78$ vs. $27.10 \mathrm{~g}$ and 3.34 vs. 3.63, respectively. However, the differences in FBW and DWG values were not significant between rabbits groups fed the $25 \%$ substitution MPM diet and the control group. The average of daily feed intake (DFI) and FCR values were better $(\mathrm{P}<0.05)$ with rabbits fed 25\% substitution MPM diet than those of the control group. The obtained values were 106.48 vs. $98.44 \mathrm{~g}$ and 3.79 vs. 3.63, respectively.

Table 5 show significant $(\mathrm{P}<0.05)$ increases in average values of FBW, DWG and DFI with adding caplix in rabbits diets compared to those fed diets without caplix. The recorded values were 2131.78 vs. $2003.77 \mathrm{~g}, 29.134$ vs. $26.841 \mathrm{gm}$ and 104.737 vs. $95.884 \mathrm{~g}$, respectively. However, adding caplix to the different experimental diets did not affect FCR values.

Also, data in Table 5 indicate that, average of FBW and daily BWG and FCR were the highest $(\mathrm{P}<0.05)$ with rabbits group fed $50 \%$ substitution MPM with adding caplix. The values were $2198 \mathrm{~g}, 30.30 \mathrm{~g}$ and 3.24, respectively. The lowest values of DBWG and DFI were recorded with rabbits fed the control diet without caplix (1984.88 $\mathrm{g}$ and $26.52 \mathrm{~g}$ ).

Generally adding moringa petioles meal to rabbit diets in substitution with levels 25 and $50 \%$ of alfalfa dehydrate meal ( 7.5 and $15 \%$ of the diet) improved the growth performance of rabbits. Talha (2013) noticed that weaned rabbits fed a diet containing $0.3 \%$ moringa leaf meal significantly $(\mathrm{P}<0.05)$ increased daily weight gain. Also, Ibrahim et al (2014) found that daily weight gain significantly increased in the rabbits fed 0.2 or $0.4 \%$ moringa seeds compared to those of control group. In broilers Safa (2012) reported that Ross broiler chicks fed diets containing Moringa oleifera leaf meal at levels of 3,5 and 7\%, gained significantly higher and superior feed conversion ratio than those fed the control diet.

\section{d. Carcass characteristics}

Data in Table 6 show that, carcass weight and total edible parts (\%) increased $(\mathrm{P}<0.05)$ with replacing 25 and $50 \%$ alfalfa dehydrate meal by 
REPLACEMENTOFALFALFAHAYBYMORINGAPETIOLES INRABBITDIETS 187

Moringa petioles meal compared to the control group. The values of dressing $\%$, liver and kidney weights were also increased $(\mathrm{P}<0.05)$ with $50 \%$ substitution level in comparison with control group. Safa (2012) found that inclusion of moringa leaf meal in broiler diets up to 5 or $7 \%$ significantly $(\mathrm{P}<0.05)$ improved hot carcass weight, dressing percentage, breast and drumstick percentages and tenderness and juiciness scores for both breast and thigh meat.

Tables 6 indicate that the values of carcass weight, dressing $\%$, liver weight and total edible parts $\%$ increased $(\mathrm{P}<0.05)$ with adding caplix to the diets in compared to those fed to the unsupplemented diets. However, adding caplix to the rabbit diets decreased $(\mathrm{P}<0.05)$ kidney weight. In this respect, Nahla et al. (2015) reported no significant differences in the hot carcass percentage were found between rabbits fed control, exogenous enzymes (ZAD) and combination of lactobacillus acidophilus and ZAD (LZ).

The highest $(\mathrm{P}<0.05)$ values of carcass weight, dressing, liver and total edible parts were recorded with rabbit's group fed 50\% substituted moringa petioles meal diet with adding caplix, while the lowest values were recorded with group fed the control diet.

\section{e - Chemical composition of rabbit meat}

Data illustrated in Table 7 show meat content moisture, CP and EE were not affected significantly by substitution of moringa petioles meal level or adding caplix. Accordingly, the interaction effect between moringa petioles meal level was not significant. Generally, Nuhu (2010) found a reduction in ether extract of meat with growing rabbits fed a diet containing $\mathrm{xx} \%$ of moringa leave meal when compared to those fed the control diet.

\section{f. Economic efficiency}

Data presented in Table 8 indicate that replacing moringa petioles meal instead of alfalfa hay at levels of 25 and $50 \%$, either with or without caplix in rabbit diets increased the net revenue and consequently improved the economic efficiency compared to the control group, while net revenue values were 16.62, 18.19 and 19.28 L.E. (without caplix) and 18.80, 18.90 and 24.12 L.E. (with caplix), respectively. The obtained values of economical efficiency (EE) were $0.406,0.457$ and 0.488 (without caplix) and 0.462 , 0.436 and 0.609 (with caplix), respectively. The relative economic efficiency (REE) was improved by 112.56 and $120.20 \%$, for rabbit fed diets without caplix, and $113.79,107.39$ and $150 \%$ for those fed diets with 
REPLACEMENTOFALFALFAHAYBY MORINGAPETIOLES INRABBITDIETS 189

Table 7. Effects of the experimental diets on rabbit meat chemical analysis (Means $\pm \mathrm{SE})$.

\begin{tabular}{|c|c|c|c|c|}
\hline Items & Moisture\% & DM\% & $\mathrm{CP} \%$ & EE\% \\
\hline \multicolumn{5}{|c|}{ Effect of replacing Moringa Petioles meal levels, \% } \\
\hline $\mathbf{0}$ & 68.09 & 31.91 & 25.09 & 2.97 \\
\hline 25 & 68.18 & 31.82 & 25.07 & 2.84 \\
\hline 50 & 68.32 & 31.69 & 25.00 & 2.86 \\
\hline SE & \pm 0.13 & \pm 0.1320 & \pm 0.1686 & \pm 0.0609 \\
\hline \multicolumn{5}{|c|}{ Effect of Caplix levels, \% } \\
\hline 0.00 & 68.24 & 31.76 & 25.00 & 2.92 \\
\hline $\begin{array}{l}\text { 0.05 } \\
\text { SE }\end{array}$ & $\begin{array}{r}68.15 \\
\pm 0.11\end{array}$ & $\begin{array}{c}31.85 \\
\pm 0.1078\end{array}$ & $\begin{array}{c}25.11 \\
\pm 0.1376\end{array}$ & $\begin{array}{c}2.86 \\
\pm 0.0497\end{array}$ \\
\hline \multicolumn{5}{|c|}{ Effect of (Moringa Petioles meal X Caplix), \% } \\
\hline $0(-)$ & 68.10 & 31.90 & 25.05 & 3.02 \\
\hline $0(+)$ & 68.08 & 31.92 & 25.13 & 2.93 \\
\hline $25(-)$ & 68.11 & 31.89 & 25.14 & 2.91 \\
\hline $25(+)$ & 68.25 & 31.75 & 25.01 & 2.78 \\
\hline $50(-)$ & 68.51 & 31.49 & 24.82 & 2.83 \\
\hline $50(+)$ & 68.12 & 31.88 & 25.19 & 2.89 \\
\hline SE & \pm 0.18 & \pm 0.1867 & \pm 0.2383 & \pm 0.0861 \\
\hline
\end{tabular}

. a, b, c ......Means within the same column with different letters are significantly different $(\mathrm{P}<0.05)$. (-) Without Caplix $\quad$ (+) With Caplix

caplix, respectively compared to the control. The improvement in EE could be attributed to the improvement in the feed conversion of rabbits fed these diets. Owen et al (2013) studied the economics of raising rabbits using Moringa olifera leaf meal as a replacement for soybean in the rabbit's feed. Their obtained results showed that significant differences existed in weight gain, feed intake, feed conversion ratio, cost of feed, cost of weight gain and net benefit.

Conclusively, replacement of $50 \%$ of alfalfa hay in the rabbits diet by moringa petioles meal with $0.05 \%$ caplex supplementation could be recommanded to improve rabbit growth performance parameters and feed efficiency of feed utilization, under the Egyptian conditions. 
Table 8. Economic efficiency as affected by subistitution of different levels of alfalfa hay by moring petioles meal with or without caplix enzyme in diets of rabbits during the experimental period.

\begin{tabular}{|c|c|c|c|c|c|c|}
\hline \multirow{4}{*}{ Items } & \multicolumn{6}{|c|}{ Replacing moringa Petioles meal (\%) } \\
\hline & \multicolumn{2}{|c|}{ 0(Control) } & \multicolumn{2}{|c|}{25} & \multicolumn{2}{|c|}{50} \\
\hline & \multicolumn{6}{|c|}{ Caplix addition } \\
\hline & $(-)$ & $(+)$ & $(-)$ & $(+)$ & $(-)$ & $(+)$ \\
\hline Total FI/rabbit kg & 5.577 & 5.448 & 5.273 & 6.652 & 5.258 & 5.496 \\
\hline Price 1kg FI (L.E.) & 2.5895 & 2.6026 & 2.5241 & 2.5311 & 2.4707 & 2.4779 \\
\hline Feed cost/ rabbit (L.E.) & 14.442 & 14.179 & 13.310 & 16.837 & 12.991 & 13.619 \\
\hline Total cost(LE)(a) & 40.94 & 40.68 & 39.81 & 43.34 & 39.49 & 39.62 \\
\hline BW & 1.9849 & 2.051 & 2.000 & 2.1463 & 2.0264 & 2.198 \\
\hline Cost/kg BW (L.E) & 20.63 & 19.83 & 19.91 & 20.19 & 19.49 & 18.03 \\
\hline Total revenue (LE)(b) & 57.56 & 59.48 & 58.00 & 62.24 & 58.77 & 63.74 \\
\hline Net revenue(L.E) & 16.62 & 18.80 & 18.19 & 18.90 & 19.28 & 24.12 \\
\hline$* \mathrm{EE}(\mathrm{c})$ & 0.406 & 0.462 & 0.457 & 0.436 & 0.488 & 0.609 \\
\hline$* * \operatorname{REE}(\mathrm{d})$ & 100 & 113.79 & 112.56 & 107.39 & 120.20 & 150.00 \\
\hline
\end{tabular}

(a) Including fixed cost (26.50L.E/rabbit), (b) Assuming that the selling price $\{$ is (29) L.E $\}$,

(C) Net revenue per unit total cost, (d) Considering the economic efficiency (EE)of the control diet without caplix $=100 \%$.

$* \mathrm{EE}=$ economical efficiency $\quad * * \mathrm{REE}=$ relative economical efficiency

(-) Without caplix, (+) With caplix at level $0.05 \%$.

\section{REFERANCE}

Abd El-Latif, S.A.; Kh.A., Mohammed; Kawsar A. Ghaly and Maha A. Abd El-Latif (2008). Effect of using commercial enzymes on performance and some metabolic functions of rabbits fed grade levels of crude fiber. Egypt. Poultry Sci. , 28 (IV): 1003-1022.

Abdel-Rahman, M. A.; F. A. R.,Sawiress and Sohair Y. Saleh.(2010). Effect of kemzyme - bentonite co-supplementation on cecal fermentation and metabolic pattern in rabbit. J. of Agric. Sci. , 2:....ين ارقام الصفحات.....

A.O.A.C. (2002). Association of Official Analytical Chemists, Washington, DC. Blasco A., J. Quhayaun and G. Masoscro (1993). Hormonization of criteria and terminology in rabbit meat research. World Rabbits Sciences, 1: 3-10. 
REPLACEMENTOFALFALFAHAYBY MORINGAPETIOLES INRABBITDIETS 191

Bolis, S.; C., Castrovilli; M., Rigoni; D., Tedescoand F.Luzi (1996). Effect of enzymes addition in diets on protein and energy utilization in rabbit. In Proc.; $6^{\text {th }}$ World Rabbit Congress, Toulouse, France, 111-115.

Booth, F.E. and G.E.,Wickens(1988).Non-timber uses of selected arid zone trees and shrubs in Africa. FAO conservation Guide, pp: 92-101, Rome.

Dorga, P.D. Sngh and S., Tandon(1975).Vitamin content in Moringa. J. Current Sci., 44: 30-31.

Dougnon, T. J.; B. A., Aboh; T. M., Kpodekon; and S. HonvouandI. (2012). Effect of substitution of pellet of Moringa oleifera to commercial feed on rabbit's digestion, growth performance and carcass trait. J. appl. pharmaceutical Sci. , 2(9):015-019.

Duncan, D.B. (1955). Multiple Range and Multiple F-Test. Biometrics, 11: 1-42.

Eiben, C. S.; M., N., Mézes; Zijártó; K., Kustos;K.,Gódor-Surmann and M., Erdélyi(2004).Dose-dependent effect of cellulose supplementation on performance of early-weaned rabbit. In Proc. $8^{\text {th }}$ World Rabbit Congress, Puebla, México, 799 - 804.

El-Badawi, A.Y.; H.A.A., Omer; A.A.,Abedo and M.H.M.,Yacout (2014). Response of growing New Zealand White rabbits to rations supplemented with different levels of Moringa oleifera dry leaves. Global Veterinaria, 12 (4): 573-582.

Fernandez, C.; J. M., Merino and R.,Carabaño (1996).Effect of enzyme complex supplementation on diets digestibility and growth performance in growing rabbits. In Proc.: $6^{\text {th }}$ World Rabbit Congress, Toulouse, France, 163-166.

Fernandez. Carmonei J.; J., Soriano; J.J., Pascual and C., Cervera (2004). The prediction of nutritive value of rabbit diets from tables of feed composition. Proceedings. $8^{\text {th }}$ World Rabbit Congress, September 7-10. PuebioMixco.

Ibrahim, N.H.; A.S., Morsy and M.E., Ashgan (2014).Effect of Moringa peregrine seed on productive performance and hemato-biochmical parameters of growing rabbits. J. Anim. Sci., 10 (6): 7-12.

Kristin, D.,2000. The Moringa Tree. Echo technical note. Florida, U.S.A.

Luqman, S.; S. Srivastava; R. Kumar; A.K.,Maurya and D.,Chanda (2012). Experimental assessment of Moringa oleifera leaf and fruits for its antistress, antioxidant and scavenging potential using in vitro and in vivo assays. Research Article, Evidence-Based complementary and Alternative Medicine, 81: 12. 
Nahla, A. Abdel-Aziz; El-Adawy M.; Maria A. Mariezcurrena-Berasain.; A. Z. M. Salem.; J. Olivares-Pérez.; A. E. Kholif and B. E. Borhami (2015). Effect of exogenous enzymes lactobacillus acidophilus or their combination on feed performance response and carcass characteristics of rabbits fed sugar cane bagasse. J. Integrative Agriculture,14(3): 544-549.

NRC (1977).National Research Council, Nutrient Requirements of Rabbits. $2^{\text {nd }}$ Rev. ed. National Academy of Sciences, Washington. D.C., USA.

Nuhu F. (2010).Effect of Moringa leaf meal (MOLM) on nutrient digestibility, growth, carcass and blood indices of weaner rabbits. MSc, Faculty of Agriculture and Natural Resources, Kwame Nkrumah University of Science and Technology, Kumasi, Ghana.

Osman, H.M.; M.E., Shayoub; and E.M., Babiker(2012). The effect of Moringa oleifera leaves on blood parameters and body weights of Albino rats and rabbits. Jordan J. of Bio. Sci., 5(3): 147-150.

Owen, O. J.; P. C. N., Alikwe and I. A. Okidim (2013). The economic potential of compounding rabbit diets with graded levels of Moringa oleifera leaf meal. J. Env. Issues Agri. in Developing Countries, 5: 34-40.

Safa M.A. El Tazi (2012). Effect of feeding different levels of Moringa oleifera leaf meal on the performance and carcass quality of broiler chicks. Int. J. Sci. and Res., ISSN (online). 3: 147-151.

Safwat, A.M.; Sarmiento-Franco and R.H., Santos-Ricalde (2014).Rabbit production using local resources as feedstuffs in the tropics. Tropical and Subtropical Agroeco Systems, 17(2014): 161-171.

SAS, (2002). Statistical Analysis System, Statistical user's Guide.Ints. Inc., Cary, NC

Sreelather, S. and P.R., Padma (2009). Antioxidant activity and total phenolic content of Moringa oleifera leaves in two stages of maturity. J. Plant Food Human Nutri, 64: 303-311.

Sullivan, L. M. (1987). Evaluation Of Sorghum Varieties In Poultry Diets. Feed Facts. Published by grain sorghum producers. Association, 4, no. 2.

Talha E.(2013). The use of Moringa oleifera in poultry diets. Turk. J. Vet. Anim. Sci., 37: 492- 496. 
REPLACEMENTOFALFALFAHAYBY MORINGA PETIOLES INRABBITDIETS 193

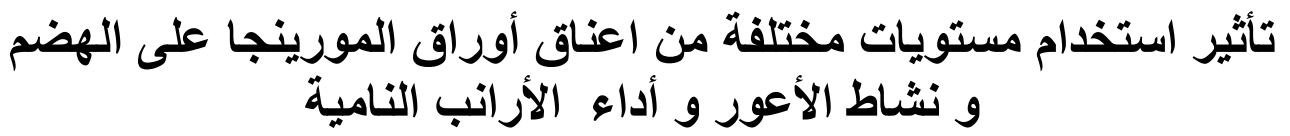

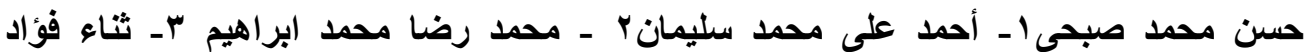

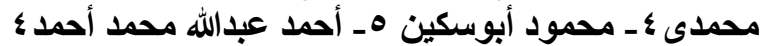

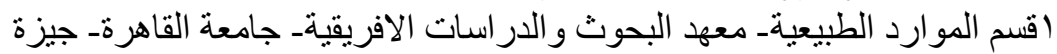

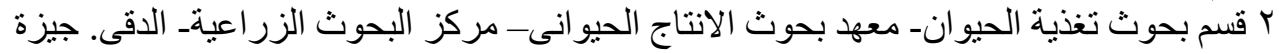

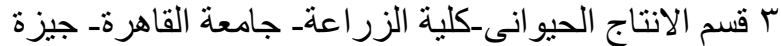

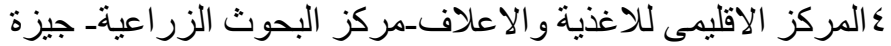
ه معهد البحوث و الدر اسات البيئية - جامعة مدينة السادات ـ المنوفية.

استخدم فى هذة الدراسة عدد VY أرنب نيوزيلاندى أبيض نامى مختلط الجنس

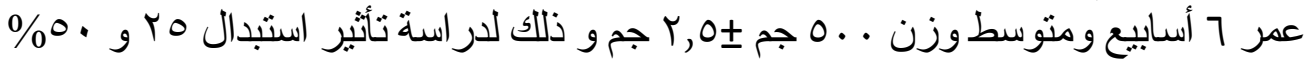

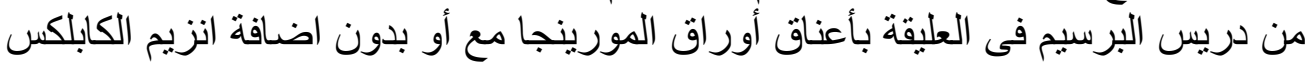

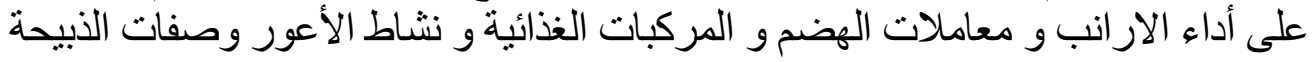

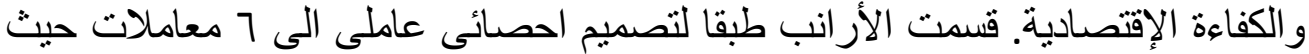

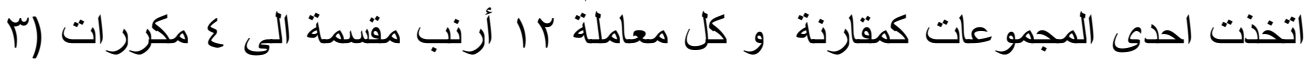

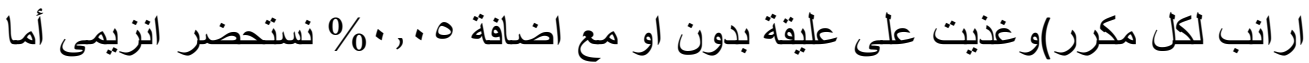

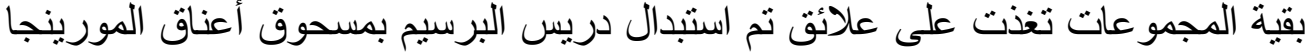

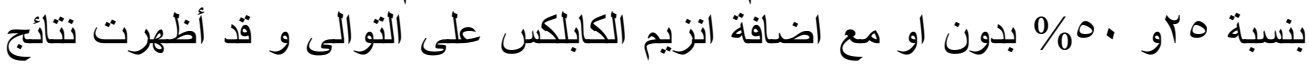

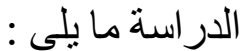

محتوى مسحوق أعناق أوراق المورينجا كان أعلى فى كلا من المادة الجافة و المادة العضوية و البروتين الخام ومستخلص الاثير و الرماد و السليلوز و الفسفور و الطاقة

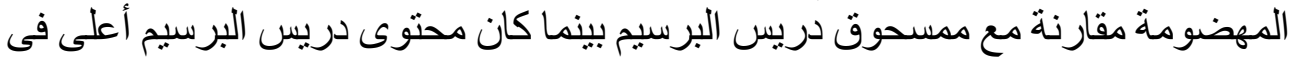

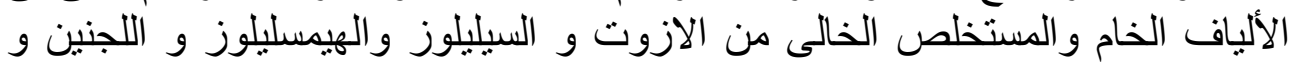

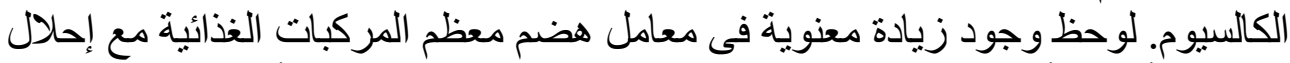

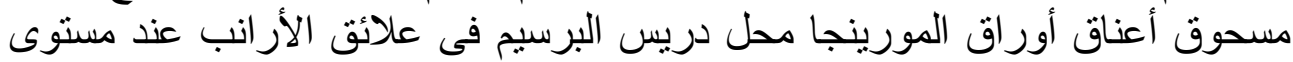

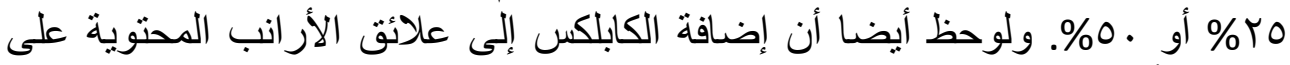

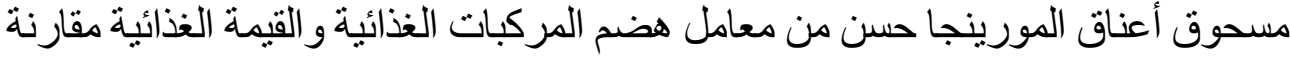

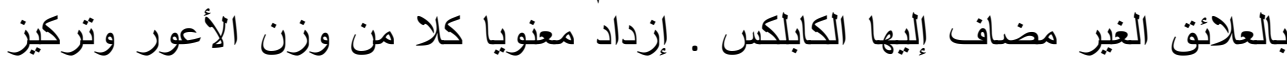

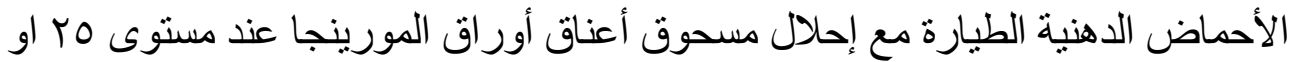

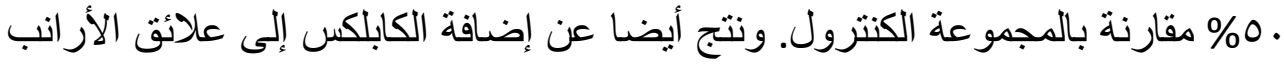


زيادة معنوية فى وزن وطول الاعور ودرجة حموضة وتركيز الاحماض الدهنية الطيارة

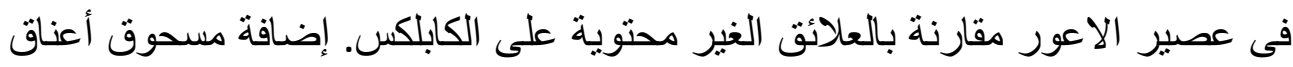

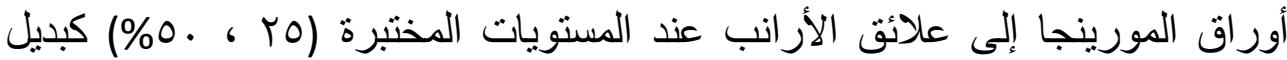

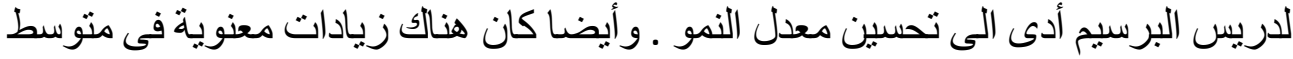
قيم و وزن الجسم النهائى وكمية الغذاء المأكول مع إضافة الكابلكس الى الى علائق الأرانب مقارنة بنالك المجاميع المغذاة على علائق بدون الكابل الكابلكس.

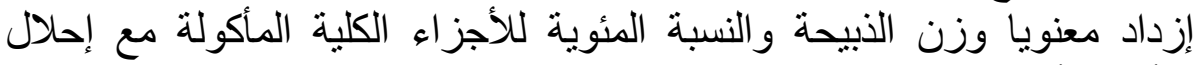

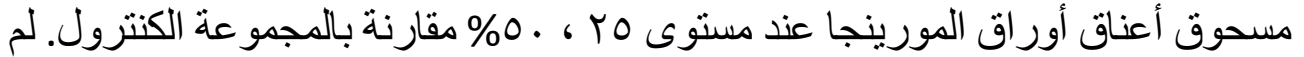

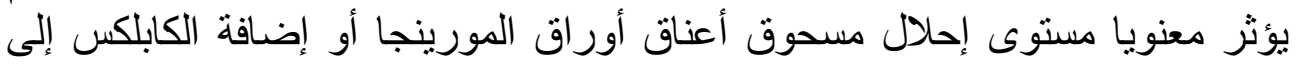

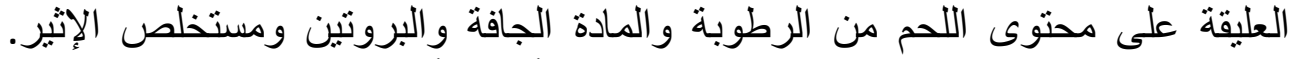

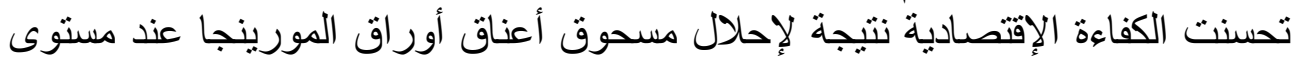

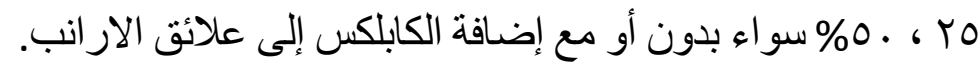

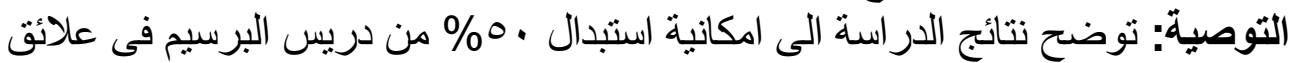

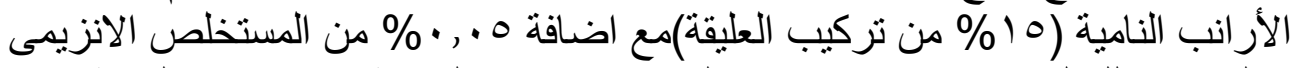
كابلكس و ذلك لتحسين مؤشرات كفاءة النمو و الاستفادة الغذائية فى الارانب النامن النامية . 